\title{
Activation of Ca-permeable Cation Channels by Myocarditis-associated Antibody in Guinea Pig Ventricular Myocytes
}

\author{
Makoto Tominaga, Akira Matsumori, Minoru Horie, Haruyoshi Yoshida, ${ }^{*}$ and Yasunobu Okada* \\ Third Department of Internal Medicine, * Second Department of Pathology, ${ }^{\ddagger}$ First Department of Physiology, \\ Faculty of Medicine, Kyoto University, Kyoto 606-01, Japan
}

\begin{abstract}
The pathogenesis of myocarditis and dilated cardiomyopathy is thought to involve autoimmunological processes and myocardial calcium overload. Serum containing antiheart antibodies associated with a murine model of myocarditis increased $\left[\mathrm{Ca}^{2+}\right]_{i}$ in guinea pig ventricular myocytes only in the presence of extracellular $\mathrm{Ca}^{2+}$. The antiheart antibody-positive serum activated $\mathrm{Ca}^{2+}$-permeable cation channels that were insensitive to dihydropyridines and membrane stretch. The permeability sequence was $\mathrm{Ba}^{2+}>\mathrm{Ca}^{2+}>\mathrm{Na}^{+} \sim \mathrm{K}^{+}$, and the single-channel conductance to $\mathrm{Ba}^{2+}$ was $12 \mathrm{pS}$. The channel was activated by extracellular application of the serum during on-cell recording, which suggests that a soluble intracellular messenger may be involved. The antibody-positive serum did not alter voltagegated $\mathrm{Ca}^{2+}$ currents. We propose that excess $\mathrm{Ca}$ entry in myocarditis and dilated cardiomyopathy results from activation of a $\mathrm{Ca}^{2+}$-permeable cationic channel by the autoantibodies. ( $\mathrm{J}$. Clin. Invest. 1993. 91:1231-1234.) Key words: antiheart antibody $\bullet$ cardiomyopathy $\bullet$ fura- $2 \cdot$ patch-clamp $\bullet$ heart muscle cell
\end{abstract}

\section{Introduction}

Several antiheart autoantibodies have been reported to be associated with the pathogenesis of myocarditis and dilated cardiomyopathy (1-8). Apparently, myocardial calcium overload is responsible for myocardial damage in myocarditis and cardiomyopathy (9). In fact, increased Ca uptake has been observed in the myocardium of cardiomyopathic hamsters $(10,11)$. Taken together, there is the possibility that circulating antiheart antibodies induce a myocardial calcium rise by increasing Ca entry.

By using the fura-2 and patch-clamp techniques, we found that the serum containing antiheart antibodies associated with

Address correspondence and reprint requests to Yasunobu Okada, M.D., Ph.D., Department of Cellular and Molecular Physiology, National Institute for Physiological Sciences, Okazaki 444, Japan.

Received for publication 1 June 1992 and in revised form 30 November 1992.

1. Abbreviations used in this paper: BAPTA, 1,2-bis(o-aminophenoxy)ethane- $N, N, N^{\prime}, N^{\prime}$-tetraacetic acid; EGTA, ethylene glycol bis ( $\beta$-amino-ethylether)- $N, N, N^{\prime}, N^{\prime}$-tetraacetic acid.

J. Clin. Invest.

(C) The American Society for Clinical Investigation, Inc. $0021-9738 / 93 / 03 / 1231 / 04 \$ 2.00$

Volume 91, March 1993, 1231-1234 a murine model of myocarditis increased the intracellular free $\mathrm{Ca}^{2+}$ concentration $\left(\left[\mathrm{Ca}^{2+}\right]_{\mathrm{i}}\right)$ through the activation of $\mathrm{Ca}^{2+}$-permeable cation channels in isolated ventricular cells of guinea pig.

\section{Methods}

Sera preparation. Sera were collected from inbred male BALB/c mice inoculated with the $M$ variant of the encephalomyocarditis virus, as previously reported (12). In several experiments, the sera were used after inactivating the complement at $56^{\circ} \mathrm{C}$ for $30 \mathrm{~min}$. The antiheart antibody-positive sera devoid of the Ig fraction were prepared from the positive sera by affinity chromatography using tresyl-activated Sepharose 4B (Pharmacia Fine Chemicals, Piscataway, NJ) and affinity-purified goat anti-mouse Ig (Cappel Laboratories, Cochranville, PA). The control antiheart antibody-negative sera were obtained from the agematched, noninfected mice. Immunofluorescence studies showed that the sera from virus-inoculated myocarditic mice, but not from noninfected mice, contain antibodies that cross-react with proteins on the surface of guinea pig ventricular myocytes (Tominaga, M., and A. Matsumori, unpublished observation).

Cell preparation. Single ventricular cells were isolated from adult Hartley guinea pig hearts using Langendorf's perfusion technique with collagenase (Yakult, Tokyo, Japan), as previously described (13).

Fura-2 experiments. The $\left[\mathrm{Ca}^{2+}\right]_{\mathrm{i}}$ was monitored by the fura- 2 fluorescence ratio, as previously described (14). Myocytes $\left(10^{4} / \mathrm{ml}\right)$ were suspended in normal Tyrode's solution containing $10 \mu \mathrm{M}$ fura- $2 /$ acetoxymethyl (Molecular Probes, Inc., Eugene, OR) and 5\% bovine serum for $30 \mathrm{~min}$ at $36^{\circ} \mathrm{C}$. The cells were then washed and stored on ice for at least $1 \mathrm{~h}$ before experiments. The fluorescence images at excitation wavelengths of 340 and $380 \mathrm{~nm}$ were collected from single ventricular myocytes at room temperature and were digitized by an image processor (Argus 100; Hamamatsu Photonics K.K., Hamamatsu City, Japan). The $\left[\mathrm{Ca}^{2+}\right]_{i}$ was estimated from the mean value of the 340:380 $\mathrm{nm}$ ratio in a given myocyte by in vivo calibration using the maximum and minimum ratio values obtained in the presence of $1 \mu \mathrm{M}$ ionomycin and $10 \mathrm{mM} \mathrm{Ca}^{2+}$ or $5 \mathrm{mM}$ ethylene glycol bis( $\beta$-amino-ethylether)- $N, N, N^{\prime}, N^{\prime}$-tetraacetic acid (EGTA).

Patch-clamp experiments. Whole-cell and cell-attached singlechannel recordings were performed with a patch-clamp amplifier (EPC-7; List, Darmstadt, Germany) at room temperature. The currents were filtered at $3 \mathrm{kHz}$ upon recordings and at $500 \mathrm{~Hz}$ on off-line data analyses. Data was sampled at 1 or $2 \mathrm{kHz}$.

Experimental solutions. Tyrode's solution contained ( $\mathrm{mM}): 143$ $\mathrm{NaCl}, 0.3 \mathrm{NaH}_{2} \mathrm{PO}_{4}, 5.4 \mathrm{KCl}, 1.8 \mathrm{CaCl}_{2}, 0.5 \mathrm{MgCl}_{2}, 5.5$ glucose and 5 Hepes- $\mathrm{NaOH}$ ( $\mathrm{pH} 7.4$ ). In some experiments, nifedipine (Bayer, Leverkusen, Germany) or Bay K 8644 (a gift from Dr. M. Kameyama, Kagoshima University, Kagoshima, Japan) was added to Tyrode's solution. Low $\mathrm{Ca}^{2+}$ Tyrode's solution was made by removing $\mathrm{CaCl}_{2}$ from and adding $10 \mu \mathrm{M}$ EGTA to normal Tyrode's solution. The free $\mathrm{Ca}^{2+}$ concentration was estimated to be $\sim 50 \mathrm{nM}$ by taking $\mathrm{Ca}^{2+}$ ions $(5$ $\mu \mathrm{M}$ ) contaminating distilled water into consideration. Low $\mathrm{Cl}^{-} \mathrm{Tyr}-$ ode's solution was made by replacing $76.5 \mathrm{mM} \mathrm{NaCl}$ with $76.5 \mathrm{mM} \mathrm{Na}$ 
gluconate. An isotonic $\mathrm{CaCl}_{2}, \mathrm{BaCl}_{2}, \mathrm{NaCl}$ or $\mathrm{KCl}$ solution contained $110 \mathrm{mM} \mathrm{CaCl}_{2}, 110 \mathrm{mM} \mathrm{BaCl}_{2}, 140 \mathrm{mM} \mathrm{NaCl}$ or $140 \mathrm{mM} \mathrm{KCl}, 8 \mathrm{mM}$ Tris, and $12 \mathrm{mM}$ Hepes ( $\mathrm{pH} 7.4)$. The control pipette solution for whole-cell recordings contained $(\mathrm{mM}): 110 \mathrm{~K}$-aspartate, $20 \mathrm{KCl}, 5$ $\mathrm{K}_{2} \mathrm{ATP}, 5 \mathrm{Na}_{2}$-creatinine phosphate, $5 \mathrm{MgCl}_{2}$, 5 EGTA, 5 Hepes and $21.1 \mathrm{KOH}(\mathrm{pH} 7.4) . \mathrm{Na}_{2}$-creatinine phosphate was removed in the experiments to determine the relative permeability to $\mathrm{K}^{+}$of $\mathrm{Ba}^{2+}$. In some experiments, $5 \mathrm{mM}$ 1,2-bis( $o$-aminophenoxy)ethane$N, N, N^{\prime}, N^{\prime}$-tetraacetic acid (BAPTA), tetrapotassium salt, was used in place of $5 \mathrm{mM}$ EGTA in the pipette solution. Patch pipettes for singlechannel recordings were filled with $110 \mathrm{mM} \mathrm{BaCl}_{2}$ and $10 \mathrm{mM}$ Hepes$\mathrm{CsOH}(\mathrm{pH} 7.4)$.

\section{Results}

By the fura-2 fluorescence ratio technique, antiheart antibodypositive sera collected from mice inoculated with encephalomyocarditis virus were found to increase $\left[\mathrm{Ca}^{2+}\right]_{\mathrm{i}}$ reversibly from $53.8 \pm 6.9(\mathrm{SD})$ to $82.3 \pm 6.8 \mathrm{nM}(n=4, P<0.01)$ in single ventricular myocytes of guinea pig (Fig. $1 \mathrm{~A}$ ). In contrast, antiheart antibody-negative sera collected from noninfected mice did not change $\left[\mathrm{Ca}^{2+}\right]_{\mathrm{i}}($ Fig. $1 \mathrm{~B})$. When the extracellular $\mathrm{Ca}^{2+}$ concentration was reduced to about $50 \mathrm{nM}$, antiheart antibody-positive sera failed to increase the $\left[\mathrm{Ca}^{2+}\right]_{\mathrm{i}}$ (Fig. $1 \mathrm{C}$ ).

Whole-cell patch-clamp experiments showed that transient inward currents are induced by puff applications of antiheart antibody-positive sera at negative potentials (Fig. $2 \mathrm{~A}$ ), but not by antiheart antibody-negative sera (Fig. $2 B$ ). When EGTA ( 5 $\mathrm{mM})$ in the pipette solution was replaced with BAPTA ( 5 $\mathrm{mM})$, essentially identical results were obtained $(n=3)$. These responses had a latency of 5-20 s. The current response diminished after repeated applications of the positive sera. In the current-clamp mode, the positive sera produced a depolarization of $4.2 \pm 2.4$ (SD) $\mathrm{mV}$ from the resting potential of $-69.9 \pm 3.3(\mathrm{SD}) \mathrm{mV}(n=8)$. This level of depolarization was not sufficient to activate voltage-gated $\mathrm{Ca}^{2+}$ channels. Neither nifedipine $(5 \mu \mathrm{M})$ nor Bay $\mathrm{K} 8644(5 \mu \mathrm{M})$ affected the seruminduced currents ( $n=4$ and 5, respectively). High voltage-activated $\mathrm{Ca}^{2+}$ currents induced by depolarization pulses $(0 \mathrm{mV}$, $300 \mathrm{~ms}$ ) applied from a holding potential at $-40 \mathrm{mV}$ in ventricular myocytes were not affected by antiheart antibody-positive sera (Fig. $2 \mathrm{~A}$ ). This was in contrast to the increase of high voltage-activated $\mathrm{Ca}^{2+}$ currents by antibodies against the ADP / ATP carrier ( 8 ). The positive sera also did not affect low voltage-activated $\mathrm{Ca}^{2+}$ currents (mainly low voltage-activated class) measured by applying depolarizing pulses $(-20 \mathrm{mV}, 60$ $\mathrm{ms}$ ) from a holding potential at $-100 \mathrm{mV}(n=3)$. The positive sera from which the Ig fraction had been removed failed to induce the inward currents (Fig. $2 C$ ). Similar current responses were also induced by the positive sera, in which the complement had been heat inactivated $(n=2)$. The positive sera-induced current response showed a reversal potential of $\sim 0 \mathrm{mV}$ and the whole-cell current-voltage relation was almost linear in Tyrode's solution (Fig. $2 \mathrm{D}$, filled circles, Inset $a$ ). Similar results were also obtained in an isotonic $\mathrm{NaCl}$ or $\mathrm{KCl}$ solution $(n=6)$. Reducing the external $\mathrm{Cl}^{-}$concentration from 153 to $76.5 \mathrm{mM}$ did not affect the current-voltage relationship $(n=5)$. The positive serum-induced inward currents were also observed in an isotonic $\mathrm{CaCl}_{2}$ (Fig. $2 \mathrm{D}$, Inset $b$ ) or $\mathrm{BaCl}_{2}$ solution (Fig. $2 \mathrm{D}$, Inset $\mathrm{c}$ ). The reversal potential was +9 and $+15 \mathrm{mV}$ in the $\mathrm{CaCl}_{2}$ and $\mathrm{BaCl}_{2}$ solutions (Fig. $2 \mathrm{D}$, open squares), respectively. The relative permeabilities of $\mathrm{Ca}^{2+}$
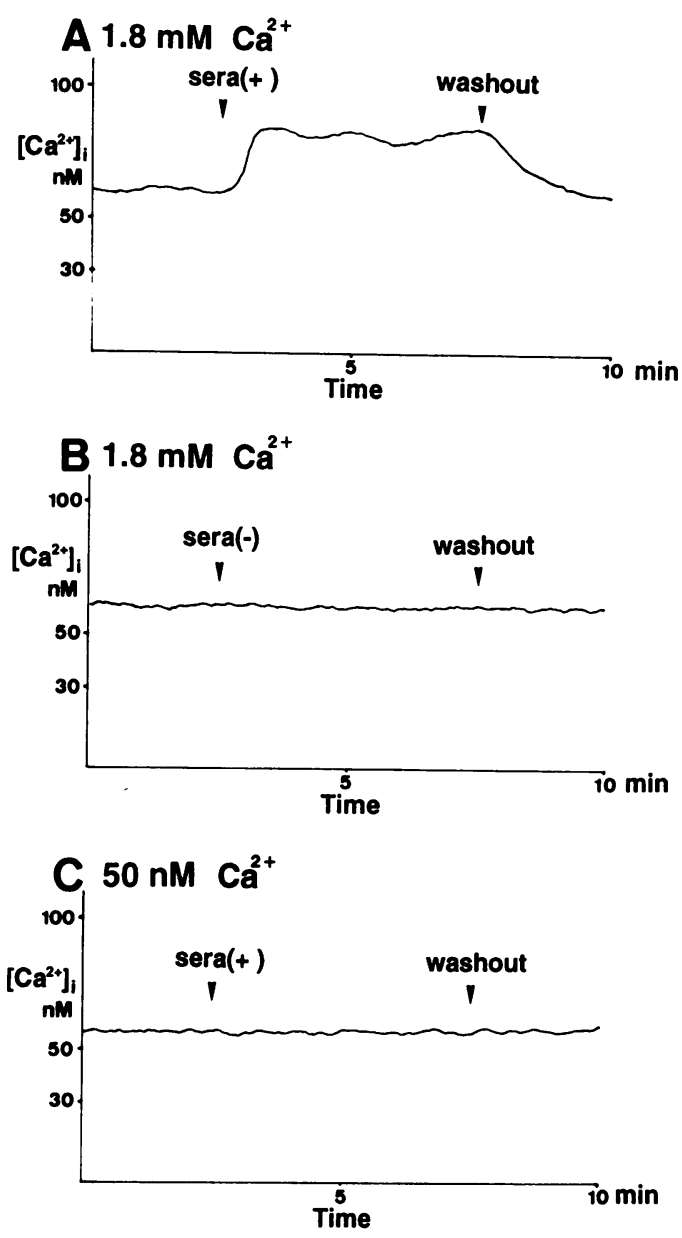

Figure 1. Effects of antiheart antibody-positive $(A$, and $C)$ and negative $(B)$ sera of mice on $\left[\mathrm{Ca}^{2+}\right]_{\mathrm{i}}$ in single ventricular cells of guinea pig. $(A) \mathrm{A}\left[\mathrm{Ca}^{2+}\right]_{\mathrm{i}}$ increase in response to antiheart antibody-positive sera $[\operatorname{ser} a(+)]$ in a ventricular myocyte in normal Tyrode's solution. $(B)$ No $\left[\mathrm{Ca}^{2+}\right]_{\mathrm{i}}$ response to antiheart antibody-negative sera $[\operatorname{sera}(-)]$ in normal Tyrode's solution. $(C)$ No $\left[\mathrm{Ca}^{2+}\right]_{\mathrm{i}}$ response to the positive sera in low $\mathrm{Ca}^{2+}$ Tyrode's solution containing $10 \mu \mathrm{M}$ EGTA. At arrowheads, the perfusate was switched from serum-free Tyrode's solution to that containing $1 \%$ sera or vice versa. The data of $A, B$, and $C$ represent four, three, and six similar experiments, respectively.

and $\mathrm{Ba}^{2+}$ to $\mathrm{K}^{+}$, estimated by the Goldman-Hodgkin-Katz equation assuming bi-ionic conditions $(110 \mathrm{mM}$ divalent cations against $161 \mathrm{mM} \mathrm{K}^{+}$), were 1.2 and 1.9 , respectively, at the macroscopic current level.

Under the cell-attached configuration, inward single-channel currents carried by $\mathrm{Ba}^{2+}$ were observed at negative membrane potentials in response to the positive sera (Fig. 3), but not to the negative sera $(n=3)$. There is a latency of $\sim 15 \mathrm{~s}$ and the current lasted for $\sim 90 \mathrm{~s}$ (Fig. $3 A$ ). The single-channel conductance determined from the unitary current-voltage plot was $\sim 12 \mathrm{pS}$ (Fig. $3 \mathrm{~B}$ ). The reversal potential estimated by extrapolation $(\sim+20 \mathrm{mV})$ agreed with that of the whole-cell current. Single-channel currents ( unitary conductance of $\sim 16$ pS) could be observed with a pipette containing normal Tyrode's solution, and this current-voltage relationship was almost linear with a reversal potential of $\sim 0 \mathrm{mV}(n=9)$. Thus, the 
A

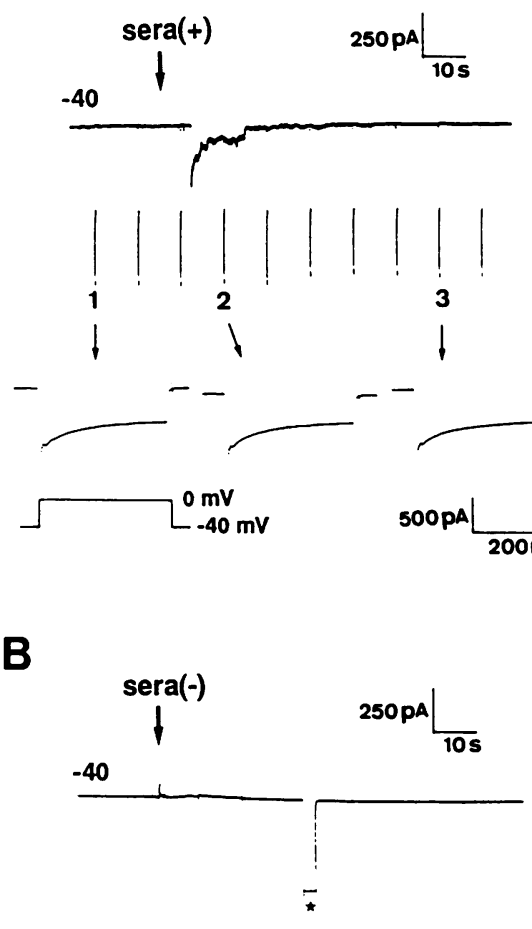

C

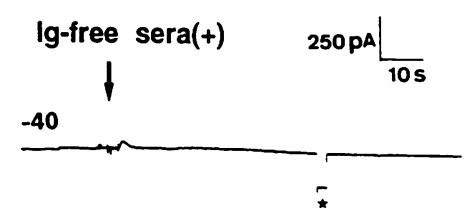

D

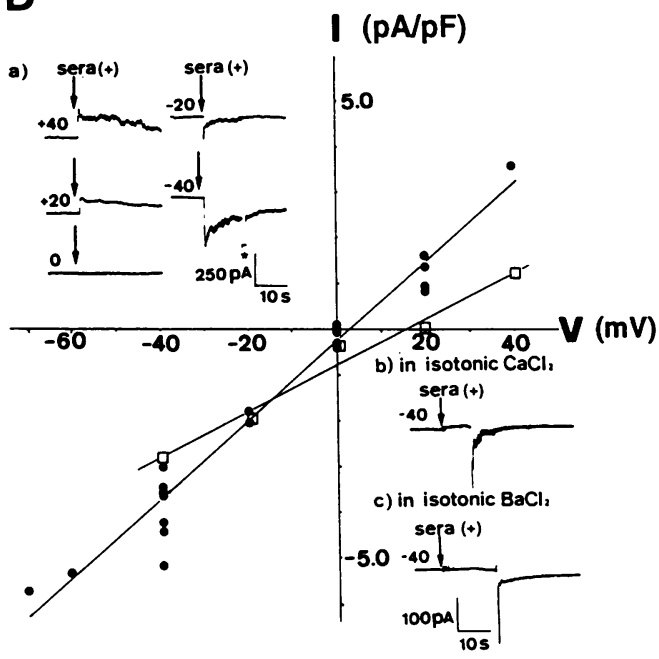

Figure 2. Effects of antiheart antibody-positive ( $A$ and $D$ ) and -negative $(B)$ sera, as well as the Ig-free-positive sera $(C)$ of mice on the whole-cell currents recorded in single ventricular cells of guinea pig. The bathing and pipette solutions were normal Tyrode's solution and the control pipette solution, respectively, unless otherwise indicated. During the current recordings, bath perfusion was interrupted. Thick arrows indicate the time of puff applications (duration $\sim 8 \mathrm{~s}$ ) of $\sim 10 \mu$ l of Tyrode's solution containing $1 \%$ sera. Inward currents are depicted as downward deflection of the trace. Holding potentials were altered from the resting potential $(-70 \mathrm{mV}$ measured by current-clamp recordings) and are indicated on the left of individual traces (in millivolts). The voltage-clamp mode was sometimes

switched to the current-clamp mode $\left(^{*}\right)$. In $A$, high voltage-activated $\mathrm{Ca}^{2+}$ currents ( sharp inward deflections) were also intermittently elicited by applying depolarizing pulses $(0 \mathrm{mV}, 300 \mathrm{~ms}$ ) (see expanded traces 1-3). In $D$, the current-voltage relationship was shown for the peak response to the positive sera bathed in normal Tyrode's solution (filled circles) and in an isotonic $\mathrm{BaCl}_{2}$ solution (open squares). (Insets) Representative current traces before and after the application of the positive sera in normal Tyrode's solution $(a)$, in the isotonic $\mathrm{CaCl}_{2}$ solution $(b)$, and in the isotonic $\mathrm{BaCl}_{2}$ solution $(c)$. The pipette solution containing BAPTA was used for the experiments in the isotonic CaCl ${ }_{2}$ solution. All the traces are representatives of four to seven separate experiments.

cation permeability sequence is $\mathrm{Ba}^{2+}>\mathrm{Na}^{+} \sim \mathrm{K}^{+}$at the microscopic current level. The antiheart antibody-activated single-channel event was not affected by dihydropyridines $(5 \mu \mathrm{M}$ nifedipine or Bay K 8644: $n=4$ ) and membrane stretch induced by suction via patch electrodes $(n=3)$.

\section{Discussion}

In the present study, we found that the antiheart antibody associated with myocarditis induces activation of $\mathrm{Ca}^{2+}$-permeable cation channels that are insensitive to dihydropyridines. Recently, $\mathrm{Ca}^{2+}$ - and $\mathrm{Ba}^{2+}$-selective background channels were found in rat ventricular cells (15). We confirmed the presence of similar channels in some guinea pig ventricular cells when cell-attached pipette contained isotonic $\mathrm{BaCl}_{2}$. However, the $\mathrm{Ca}^{2+}$ - and $\mathrm{Ba}^{2+}$-selective background channel appears to be different from the antiheart antibody-activated cation channel because $(a)$ the former (but not the latter) was activated by dihydropyridines; $(b)$ the former had a larger channel conductance to $\mathrm{Ba}^{2+}(\sim 17 \mathrm{pS})$ than the latter $(12 \mathrm{pS}) ;(c)$ the reversal potential for the former channel (measured under the same conditions, as in Fig. 3 ) was more positive $(\sim+59 \mathrm{mV})$ than that for the latter channel; and $(d)$ the antiheart antibody-positive sera did not alter the former channel activity. The antibody-activated channel is also distinct from the $\mathrm{Ca}^{2+}$-activated nonselective cation channel reported in guinea pig ventricular myocytes (16), since the antiheart antibody-activated nonselective cation current was not abolished by chelation of cytosolic $\mathrm{Ca}^{2+}$ with $5 \mathrm{mM}$ BAPTA.

Autoantibodies associated with myasthenia gravis and the Lambert-Eaton myasthenic syndrome are known to act by directly binding to acetylcholine receptor channels (17) and voltage-gated $\mathrm{Ca}^{2+}$ channels (18-20), respectively. In contrast, antiheart antibody-positive sera added to the bath could activate the channels in the cell-attached patch membrane to which the sera could not gain access. This and the long latency of the response suggest the involvement of some intracellular messengers in channel activation.

The pathogenesis of myocarditis and cardiomyopathy has been suggested to involve autoimmunity (1-3), as well as calcium overload (9-11). Antibodies against the ADP/ATP carrier have been shown to enhance high voltage-activated $\mathrm{Ca}^{2+}$ channels (8). The dihydropyridine-binding sites in heart muscle were reported to increase in the Syrian cardiomyopathic hamster $(21,22)$, but this remains controversial (23). Here we showed that dihydropyridine-insensitive $\mathrm{Ca}^{2+}$-permeable cation channels, but not voltage-gated $\mathrm{Ca}^{2+}$ channels, are activated by antiheart antibodies associated with myocarditis in guinea pig ventricular myocytes. It is likely that excess $\mathrm{Ca}$ entry caused by activation of this novel channel by the disease-associated antibodies is involved in the pathogenesis of myocarditis and dilated cardiomyopathy. 
A
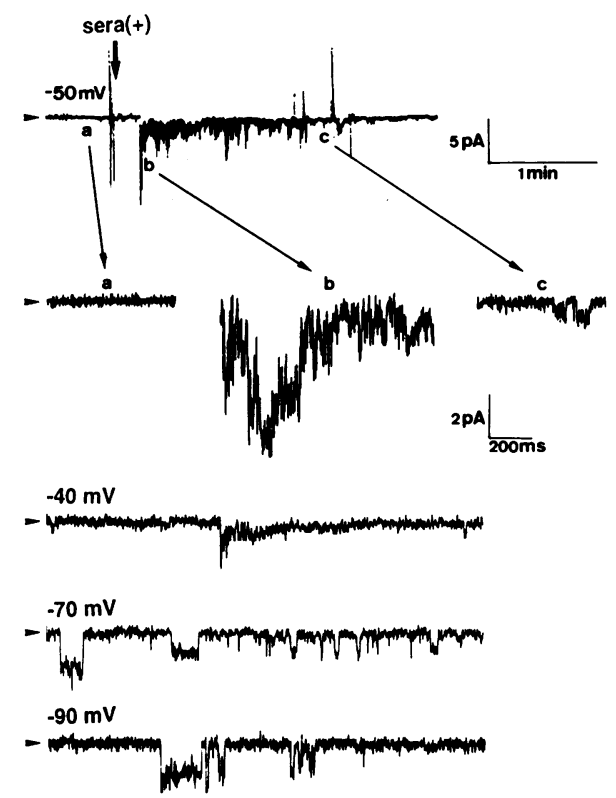

B

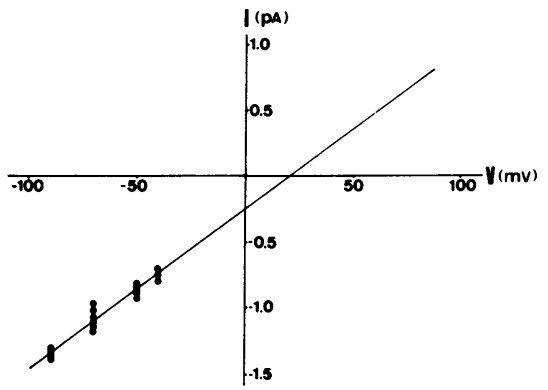

Figure 3. $\mathrm{Ba}^{2+}$-permeable single-channel activities induced by antiheart antibody-positive sera at various holding potentials in cell-attached patches on guinea pig ventricular cells bathed in normal Tyrode's solution. The pipette solution contained $110 \mathrm{mM} \mathrm{Ba}^{2+}$. (A) Representative traces of the serum-induced channel activities in four different patches at $-40,-50,-70$, and $-90 \mathrm{mV}$. Membrane potentials were estimated by assuming that the intracellular potential is equal to $-70 \mathrm{mV}$. A thick arrow indicates the time of puff application (duration $\sim 8 \mathrm{~s}$ ) of the positive sera. The sera were added 40-47 s before recording of the lower three traces. Downward deflections of the current trace represent inward currents. $(a-c)$ Expanded traces of parts of the top trace. The closed level is marked by arrowheads. $(B)$ Current-voltage (I-V) relationship. At more positive potentials than $-40 \mathrm{mV}$, isolation of the antiheart antibody-activated channel activities was difficult because the activities were contaminated by other kinds of channels.

\section{Acknowledgments}

The authors are grateful to Prof. M. Kuno (Kyoto University, Kyoto, Japan) and Prof. S. G. Schultz (University of Texas, Houston, TX) for reading the manuscript, and to Dr. A. F. James (International Research Laboratories, Ciba-Geigy, Ltd., Takarazuka, Japan) for assistance in preparing the manuscript.

\section{References}

1. Kereiakes, D. J., and W. W. Parmley. 1984. Myocarditis and cardiomyopathy. Am. Heart J. 108:1318-1326.

2. Kawai, C., A. Matsumori, and H. Fujiwara. 1987. Myocarditis and dilated cardiomyopathy. Annu. Rev. Med. 38:221-239.

3. Schultheiss, H. P. 1989. The significance of autoantibodies against the ADP/ATP carrier for the pathogenesis of myocarditis and dilated cardiomyopathy. Springer Semin. Immunopathol. 11:15-30.

4. Das, S. K., J. T. Cassidy, and R. E. Petty. 1972. Antibodies against heart muscle and nuclear constituents in cardiomyopathy. Am. Heart J. 83:159-166.

5. Wolfgram, L. J., K. W. Beisel, and N. R. Rose. 1985. Heart-specific autoantibodies following murine coxackievirus B3 myocarditis. J. Exp. Med. 161:11121121.

6. Limas, C. J., I. F. Goldenberg, and C. Limas. 1989. Auto-antibodies against $\beta$-adrenoceptors in human idiopathic dilated cardiomyopathy. Circ. Res. 64:97103.

7. Caforio, A. L. P., E. Bonifacio, J. T. Stewart, D. Neglia, O. Parodi, G. F. Bottazzo, and W. J. McKenna. 1990. Novel organ-specific circulating cardiac autoantibodies in dilated cardiomyopathy. J. Am. Coll. Cardiol. 15:1527-1534.

8. Schultheiss, H. P., U. Kuhl, I. Janda, B. Melzner, G. Urlich, and M. Morad. 1988. Antibody-mediated enhancement of calcium permeability in cardiac myocytes. J. Exp. Med. 168:2105-2119.

9. Weisman, H. F., and M. L. Weisfeldt. 1987. Toward an understanding of the molecular basis of cardiomyopathy. J. Am. Coll. Cardiol. 10:1135-1138.

10. Lossnitzer, K., J. Janke, B. Hein, M. Stauch, and A. Fleckenstein. 1975. A disturbed myocardial calcium metabolism: a possible pathogenetic factor in the hereditary cardiomyopathy of the Syrian hamster. In Recent Advance in Studies on Cardiac Structure and Metabolism. A. Fleckenstein and G. Rona, editors. University Park Press, Baltimore, MD. 205-217.

11. Sen, L., M. O'Neill, J. D. Marsh, and T. W. Smith. 1990. Myocyte structure, function, and calcium kinetics in the cardiomyopathic hamster heart. Am.J. Physiol. 259:H1533-1543.

12. Matsumori, A., and C. Kawai. 1982. An experimental model for congestive heart failure after encephalomyocarditis virus myocarditis in mice. Circulation. 65:1230-1235.

13. Horie, M., H. Irisawa, and A. Noma. 1987. Voltage-dependent magnesium block of adenosine-triphosphate-sensitive potassium channel in guinea-pig ventricular cells. J. Physiol. (Camb.). 387:251-272.

14. Ueda, S., and Y. Okada. 1989. Acid secretagogues induce $\mathrm{Ca}^{2+}$ mobilization coupled to $\mathrm{K}^{+}$conductance activation in rat parietal cells in tissue culture. Biochim. Biophys Acta. 1012:254-260.

15. Coulombe, A., I. A. Lefevre, I. Baro, and E. Coraboeuf. 1989. Barium- and calcium-permeable channels open at negative membrane potentials in rat ventricular myocytes. J. Membr. Biol. 111:57-67.

16. Ehara, T., A. Noma, and K. Ono. 1988. Calcium-activated nonselective cation channels in ventricular cells isolated from adult guinea-pig hearts. J. Physiol. (Camb.). 403:117-133.

17. Drachman, D. B. 1988. Myasthenia gravis: immunobiology of a receptor disorder. Trends Neurosci. 11:446-451.

18. Kim, Y. I., and E. Neher. 1988. IgG from patients with Lambert-Eaton syndrome blocks voltage-dependent calcium channels. Nature (Lond.). 239:405408.

19. Peers, C., B. Lang, J. Newson-Davis, and D. W. Wray. 1990. Selective activation of myasthenic syndrome antibodies on calcium channels in a rodent neuroblastomaxglioma cell line. J. Physiol. (Camb.). 421:293-308.

20. Sher, E., E. Biancardi, M. Passafaro, and F. Clementi. 1991. Physiopathology of neuronal voltage-operated calcium channels. FASEB (Fed. Am. Soc. Exp. Biol.) J. 5:2677-2683.

21. Finkel, M. S., E. S. Marks, R. E. Patterson, E. H. Speir, K. Steadman, and H. R. Keiser. 1986. Increased cardiac calcium channels in hamster cardiomyopathy. Am. J. Cardiol. 57:1205-1206.

22. Wagner, J. A., I. J. Reynolds, H. F. Weisman, P. Dudeck, M. L. Weisfeldt, and S. H. Snyder. 1986. Calcium antagonist receptors in cardiomyopathic hamster: selective increase in heart, muscle, brain. Science (Wash. DC). 232:515518.

23. Howlett, S. E., J. F. Rafuse, and T. Gordon. 1988. $\left[{ }^{3} \mathrm{~N}\right]-$ Nitrendipine binding sites in normal and cardiomyopathic hamsters: absence of a selective increase in putative calcium channels in cardiomyopathic hearts. Cardiovasc. Res. 22:840-846. 